\title{
Profesor CASIMIRO DAZA PLATA
}

Sorpresa dolorosa ha sido la que en todos ha ocasionado la muerte casi repentina del doctor y profesor Casimiro Daza Plata, conocida y prestante personalidad del cuerpo médico, primordial_ mente de la Sociedad Colombiana de Obstetricia y Ginecología, para cuya fundación en 1943 se entusiasmara ai unísono con los jefes de clínica obstétrica de aquella recordada y feliz época.

Constituyó la clara significación de lo que vale el esfuerzo individual en la vida del hombre y del médico. Con espontaneidad y vehemencia de triunfo, animado por una voluntad tesonera, vino de ia Costa Atlántica hasta la capital de la República, y sin desvincularse de pueblo ni de ésta, con sus propios recursos y constante aferración al trabajo, se graduó después de haber sido estudiante cumplido, celoso de sus compromisos universitarios, como así lo atestiguan sus maestros y compañeros, para luego desfilar por la entonces atractiva carrera del profesorado - mira o albergue de los profesionales independientes-, y así percibir la retribución que prodigaban ios concursos, a pesar de sus posi_ bles defectos siempre minoritarios y no mayoritarios, con los títulos merecidos en el internado, jefatura de clínica obstétrica, preparaduría, jefatura de trabajos, agregación y titular de Química Biológica, y que los anteriores fueran los puntales sólidos que le sirvieran para consolidar una meritoria existencia, consagrada a una faena cuotidiana, a ia docencia, al ejercicio profe. sional, al laboratorio y a la obstetricia, para todo lo cual sacaba tiempo y en lo que era admirado por sus dotes de actividad, amenidad, competencia, controversias, corrección y puntualidad.

Desde el funcionamiento de los Seguros sociales —que aún provocan polémicas y jamás elias cesarán-, les prestó su colaboración efectiva como obstetra práctico que siempre confiaba 
en el triunfo del parto espontáneo, discutía y resolvía las conductas después del diagnóstico sencillo o común, sin pensar ni buscar lo raro, excepcional o complicado, como quiera que se disciplinó en ias enseñanzas y experiencias de la maternidad de San Juan de Dios de Bogotá, más las de la clásica Escuela Obstétrica Francesa.

Con la súbita desaparición de Casimiro Daza, otro caso más como el del infarto cardíaco, que traduce la actividad fisiológica de las arteriolas cerebrales dei médico, y que extinguen su vida, la Sociedad Colombiana de Obstetricia y Ginecología ha experi. mentado un duelo intenso, que comprobó en el minuto de silencio y la misa solemne que le dedicara, y tanto la Sociedad como ia Revista comparten el sentimiento de dolor que apena a su distinguida esposa, hijos y familiares al tiempo que honran la me. moria de tan querido colega, lo destacan como ejemplo de cabaliero, amigo, médico y obstetra.

R. P. C. 